\title{
Atlantic salmon require long-chain $n-3$ fatty acids for optimal growth throughout the seawater period
}

\author{
Grethe Rosenlund ${ }^{1}$, Bente E. Torstensen ${ }^{2}$, Ingunn Stubhaug ${ }^{1}$, Nafiha Usman ${ }^{1}$ and Nini H. Sissener ${ }^{2}$ \\ ${ }^{1}$ Skretting Aquaculture Research Centre, PO Box 48, 4001 Stavanger, Norway \\ ${ }^{2}$ National Institute of Nutrition and Seafood Research (NIFES), PO Box 2029, Strandgaten 229, 5817 Bergen, Norway
}

(Received 20 February 2016 - Accepted 2 March 2016)

Journal of Nutritional Science (2016), vol. 5, e19, page 1 of 13

doi:10.1017/jns.2016.10

Abstract

The nutritional requirement for $n$ - 3 long-chain PUFA in fast-growing Atlantic salmon (Salmo salar) during grow out in the sea is not well documented. Diets were formulated with levels of EPA $(20: 5 n-3)$ and DHA (22:6n-3) ranging from 1.3 to $7.4 \%$ of fatty acids (4-24 g/ $\mathrm{kg}$ feed). Two long-term trials were conducted through the seawater phase, the first at 6 and $12{ }^{\circ} \mathrm{C}$, and the second at $12^{\circ} \mathrm{C}$. In the first trial, growth at both temperatures was significantly lower in fish fed $1.4 \% \mathrm{EPA}+\mathrm{DHA}$ of total fatty acids compared with the $5.2 \% \mathrm{EPA}+\mathrm{DHA}$ group. In the second trial, growth was significantly lower in fish fed 1.3 and $2.7 \%$ compared with 4.4 and $7.4 \%$ EPA + DHA. Fatty acid composition in the fish reflected diet composition, but only after a 7 -fold increase in body weight did the fatty acid profile of the fish stabilise according to dietary fatty acids (shown for EPA and DHA). The retention efficiency of DHA increased with decreasing dietary levels, and was 120-190 and 120-200\% in trials 1 and 2, respectively. The retention efficiency of EPA was lower (60$200 \%$ ), and values $>100 \%$ were only achieved at the lowest dietary levels in both trials. Temperature did not affect fatty acid retention efficiency. These results suggest that Atlantic salmon have a specific requirement for EPA + DHA $>2.7 \%$ of fatty acids for optimal long-term growth in seawater, and that short-term growth trials with less weight increase would not show these effects.

Key words: Atlantic salmon: $n$-3 Fatty acids: Fish requirements: Growth performance in seawater

If fish oil (FO) inclusion in salmon feeds is to be kept at current levels, the supply of FO is the single factor that in the short term will limit further growth in production ${ }^{(1)}$. The exact requirement of Atlantic salmon (Salmo salar) for the longchain PUFA (LC-PUFA) EPA (20:5n-3) and DHA (22 : $6 n-3)$ is not known, but levels around $5-10 \mathrm{~g} / \mathrm{kg}$ feed $(1 \cdot 5-$ $3 \cdot 0 \%$ of lipids) have been suggested ${ }^{(2,3)}$. It is also possible that the requirements of salmon for these fatty acids (FA) at the tissue level could be fulfilled by dietary $\alpha$-linolenic acid (18 : 3n-3, LNA), which then requires desaturation and elongation to EPA and DHA by the fish, mainly in the liver ${ }^{(2)}$. Adequate tissue levels of EPA and DHA are important to maintain fish health, as they play key roles in ontogenesis, growth, survival, pigmentation and resistance to stress and disease as well as in the development and functionality of the brain, vision and nervous system ${ }^{(2)}$.

In rainbow trout (Oncorbynchus mykiss), it was shown early on that $n-3$ FA (LNA and LC-PUFA) were essential for good growth and survival ${ }^{(4,5)}$. Diets with no fat or only oleic acid resulted in poor growth and clear deficiency symptoms such as fin damage, increased liver index, pale livers, histological changes in the heart and reduced survival. Some of these symptoms were partially alleviated by adding n-6 PUFA, while $n-3$ PUFA and LC-PUFA were demonstrated to be superior $^{(5)}$. Including LNA or $n$-3 LC-PUFA in maize oil diets (high $n-6 \mathrm{FA}$ ) resulted in increased growth and better

Abbreviations: BW, body weight; EFA, essential fatty acid; FA, fatty acid; FCR, feed conversion ratio; FO, fish oil; LC-PUFA, long-chain PUFA; LNA, $\alpha$-linolenic acid; PL, phospholipid; SGR, specific growth rate; TGC, thermal growth coefficient; VO, vegetable oil.

* Corresponding author: G. Rosenlund, fax +47 51825501, email grethe.rosenlund@skretting.com 
survival $^{(4)}$. Studies in Atlantic salmon in freshwater have shown that $10 \mathrm{~g} / \mathrm{kg}$ feed as $n-3 \mathrm{FA}$ gave better growth, and fish fed a mixture of EPA and DHA grew better than fish fed only LNA ${ }^{(6)}$. All of the above studies were, however, conducted with semi-synthetic diets with low lipid content, resulting in poor growth, thus they are not directly applicable to the aquaculture industry today, with high-lipid diets and fast-growing fish. In view of these changes essential FA (EFA) requirements in important aquaculture species should be reassessed and in particular the understanding of the dietary needs for $n$-3 LC-PUFA must be improved ${ }^{(7)}$. Many studies have been conducted with Atlantic salmon in seawater replacing up to $100 \%$ of the $\mathrm{FO}$ in the diets with vegetable oils $(\mathrm{VO})$ in the grow-out stage in seawater ${ }^{(8,9-20)}$. However, the diets used in these studies contained fish meal as the main protein source, which also contains phospholipids (PL) rich in EPA and DHA, resulting in dietary levels of EPA + DHA at $10 \mathrm{~g} / \mathrm{kg}$ and above. Hence, the EPA and DHA contents were not probably a limiting factor in these studies. Thus, there is a need for trials looking at the effects of low dietary EPA and DHA in fast-growing Atlantic salmon in the seawater stage assuring that weight gain is sufficient to minimise the effects of initial body levels of these FA.

During production in the sea, Atlantic salmon are exposed to seasonal variations in environmental temperature. Modification of FA composition in membrane PL is a major response to thermal change, and decreasing temperature will result in a greater proportion of PUFA in the membranes ${ }^{(21-23)}$. These changes are associated with changes in mitochondrial oxidative capacities. In particular, the content of EPA and DHA varies inversely with the content of 18 : $1 n-9$ and $18: 2 n-6$ as temperature increases ${ }^{(23)}$. Hence, temperature may affect the requirement for EPA and DHA in Atlantic salmon for maintaining membrane functionality.

It has been shown that Atlantic salmon can be a net producer of $\mathrm{DHA}^{(20)}$. However, despite some de novo biosynthesis, tissue levels of DHA are reduced in fish fed VO compared with fish fed FO. Additionally, net production of DHA was only shown during a period with high growth and low DHA content in the diet ${ }^{(20)}$. Rainbow trout fed linseed oil can also be a net producer of EPA and DHA, as the amount recovered in fish was more than twice what the fish had been fed $^{(24)}$. In salmonids fed linseed oil as the sole lipid source in the diet, liver FA desaturation and elongation activity was increased 2.6-fold, but tissue levels similar to fish fed FO could not be maintained ${ }^{(25,26)}$. Increased elongation and desaturation of LNA to EPA and DHA have been shown in hepatocytes isolated from Atlantic salmon fed EFA-deficient $\operatorname{diets}^{(27)}$.

The aim of the present study was to determine if low dietary levels of EPA and DHA, in the presence of LNA, affect the growth of Atlantic salmon in the seawater stage corresponding to $>20$-fold increase in body weight (BW). Furthermore, we aimed to elucidate if the requirement was affected by temperature, and also how the FA composition of whole fish and fillet, as well as the FA retention efficiency were affected by low dietary EPA and DHA contents.

\section{Materials and methods}

\section{Feeding trials}

Two long-term growth trials were conducted with Atlantic salmon (Salmon salar L.) in seawater using a regression design. In both trials all fish were individually tagged with microtransponders (RFID tags; Trac Id Systems). For each pellet size and trial the experimental diets were produced from a common dry extruded feed kernel and differed only in the combination of oils added to the kernel. The diets were formulated to contain a gradient of EPA and DHA ranging from 1 to $5 \%$ and from 1 to $7.5 \%$ of total $\mathrm{FA}$ in trials 1 and 2 , respectively (Tables 1 and 2, Supplementary Tables S1-S5). The main oil source added was a blend of plant oils (rapeseed-palm-linseed; 55:30:15) ${ }^{(18)}$ and the experimental gradient in EPA + DHA was obtained by including 0 to $35 \%$ FO in the total oil mix added to the diets. Feeds were produced as 4, 6 and $8 \mathrm{~mm}$ pellets according to fish size. The fish meal level was kept constant at $10 \%$ in all pellet sizes, but crude protein and lipid contents were formulated according to commercial salmon diets (Skretting, Norway), i.e. crude protein was formulated to 470,430 and $380 \mathrm{~g} / \mathrm{kg}$ and total lipid to 300,320 and $340 \mathrm{~g} / \mathrm{kg}$ in 4,6 and $8 \mathrm{~mm}$ pellets, respectively.

In trial 1, 750 Atlantic salmon, mean BW 162 (SEM 0.9) g, were evenly distributed in five circular tanks (diameter $3 \mathrm{~m}$, 7000 litres) supplied with flow-through seawater at $12^{\circ} \mathrm{C}$. The photoperiod was $24 \mathrm{~h}$ light. Fish in each tank were fed one of the five experimental diets with graded levels of $\mathrm{EPA}+\mathrm{DHA}$ from 1.4 to $5.2 \%$ of total FA for a run-in

Table 1. Composition and proximate composition $(\mathrm{g} / \mathrm{kg})$ of the experimental diets $(8 \mathrm{~mm})$ used in trial 1 from about $1500 \mathrm{~g}$ body weight (diets for trial 2 were formulated accordingly using the same raw materials)

\begin{tabular}{|c|c|c|c|c|c|}
\hline Diet... & $1: 1 \cdot 4$ & $1: 2 \cdot 7$ & $1: 3 \cdot 4$ & $1: 4 \cdot 3$ & $1: 5 \cdot 2$ \\
\hline \multicolumn{6}{|l|}{ Ingredients } \\
\hline Fishmeal $^{*}$ & 100 & 100 & 100 & 100 & 100 \\
\hline Wheat gluten $†$ & 114 & 114 & 114 & 114 & 114 \\
\hline $\begin{array}{l}\text { Sunflower-seed } \\
\text { mealł }\end{array}$ & 40 & 40 & 40 & 40 & 40 \\
\hline $\begin{array}{c}\text { Faba beans, } \\
\text { dehulled§ }\end{array}$ & 60 & 60 & 60 & 60 & 60 \\
\hline Soya concentrate\| & 275 & 275 & 275 & 275 & 275 \\
\hline Wheat§ & 50 & 50 & 50 & 50 & 50 \\
\hline Fish oilף & 0 & $22 \cdot 4$ & 43.5 & 64.6 & 85.7 \\
\hline Rapeseed oil§ & $175 \cdot 0$ & 161.9 & 150.3 & 138.7 & $127 \cdot 1$ \\
\hline Palm oil ${ }^{\star *}$ & 94.5 & 88.3 & $82 \cdot 0$ & $75 \cdot 7$ & $69 \cdot 3$ \\
\hline Linseed oil†† & 47.2 & $44 \cdot 1$ & 41.0 & $37 \cdot 8$ & 34.7 \\
\hline Premixesł‡ & $44 \cdot 30$ & $44 \cdot 30$ & $44 \cdot 30$ & $44 \cdot 30$ & $44 \cdot 30$ \\
\hline \multicolumn{6}{|l|}{ Proximate composition } \\
\hline Protein & 395 & 385 & 388 & 388 & 389 \\
\hline Fat & 355 & 359 & 356 & 348 & 352 \\
\hline Moisture & 60 & 60 & 62 & 64 & 68 \\
\hline
\end{tabular}

* Scandinavian fishmeal (Skretting).

† Cargill Cerestar.

$\ddagger$ Linas Agro AS

$\S$ Skretting.

II Selecta.

IN Northern hemisphere fish oil (Skretting)

** Palmolein, Fritex 24 (Aarhus Karlshamns).

†† Elbe Fetthandel $\mathrm{GmbH}$.

㧊 Include vitamins and minerals (Trouw Nutrition), proprietary composition Skretting ARC, vitamin and mineral supplementation as estimated to cover requirements according to the National Research Council ${ }^{(3)}$. 
Table 2. Fatty acid composition (\% of total FA) in the $8 \mathrm{~mm}$ diets used in trials 1 and 2

\begin{tabular}{|c|c|c|c|c|c|c|c|c|c|}
\hline \multirow[b]{2}{*}{ Fatty acids } & \multicolumn{9}{|c|}{ Diet } \\
\hline & $1: 1.4$ & $1: 2 \cdot 7$ & $1: 3 \cdot 4$ & $1: 4 \cdot 3$ & $1: 5 \cdot 2$ & $2: 1 \cdot 3$ & $2: 2 \cdot 7$ & $2: 4.4$ & $2: 7 \cdot 4$ \\
\hline \multicolumn{10}{|l|}{ Saturates } \\
\hline $14: 0$ & 0.6 & 1.2 & 1.6 & 1.9 & $2 \cdot 4$ & 0.7 & $1 \cdot 1$ & 1.7 & $3 \cdot 2$ \\
\hline $16: 0$ & 14.8 & 14.8 & 14.9 & $15 \cdot 0$ & $15 \cdot 1$ & $15 \cdot 1$ & 14.9 & $15 \cdot 0$ & 14.5 \\
\hline $18: 0$ & $2 \cdot 3$ & $2 \cdot 2$ & $2 \cdot 1$ & $2 \cdot 2$ & $2 \cdot 2$ & 2.5 & $2 \cdot 3$ & 2.6 & 2.6 \\
\hline Sum saturates & $18 \cdot 3$ & $19 \cdot 0$ & $19 \cdot 3$ & $19 \cdot 9$ & $20 \cdot 4$ & $19 \cdot 1$ & $19 \cdot 1$ & $20 \cdot 2$ & 21.4 \\
\hline \multicolumn{10}{|l|}{ Monoenes } \\
\hline $16: 1 n-7 / 9$ & 0.6 & 1.2 & 1.5 & 1.9 & $2 \cdot 3$ & 0.6 & $1 \cdot 1$ & 1.8 & 3.0 \\
\hline $18: 1 n-9 / 7$ & $42 \cdot 8$ & $42 \cdot 4$ & 39.1 & $37 \cdot 7$ & $35 \cdot 6$ & $42 \cdot 7$ & $40 \cdot 7$ & 37.8 & 31.8 \\
\hline $20: 1 n-9$ & 1.3 & 1.7 & $2 \cdot 0$ & $2 \cdot 3$ & $2 \cdot 6$ & 1.5 & 1.8 & $2 \cdot 3$ & $3 \cdot 1$ \\
\hline $22: 1 n-11 / 9$ & 0.8 & 1.4 & 1.8 & $2 \cdot 2$ & $2 \cdot 6$ & $1 \cdot 1$ & 1.4 & $2 \cdot 2$ & 3.7 \\
\hline Sum monoenes & $45 \cdot 9$ & $45 \cdot 3$ & $45 \cdot 0$ & $44 \cdot 7$ & 43.7 & 46.4 & 45.5 & 44.5 & $42 \cdot 2$ \\
\hline \multicolumn{10}{|l|}{$n-6$ Fatty acids } \\
\hline $18: 2 n-6$ & $16 \cdot 6$ & $15 \cdot 6$ & 14.8 & $14 \cdot 3$ & 13.5 & 16.5 & $15 \cdot 6$ & 14.3 & 12.6 \\
\hline $20: 4 n-6$ & 0.0 & 0.1 & 0.1 & 0.1 & 0.2 & 0.0 & 0.1 & 0.2 & 0.3 \\
\hline Sum $n-6$ & $16 \cdot 7$ & $16 \cdot 0$ & $15 \cdot 2$ & 14.8 & $14 \cdot 2$ & $16 \cdot 6$ & 15.9 & 14.8 & 13.5 \\
\hline \multicolumn{10}{|l|}{$n$-3 Fatty acids } \\
\hline $18: 3 n-3$ & 13.2 & $12 \cdot 0$ & 11.5 & $10 \cdot 7$ & $10 \cdot 1$ & 11.7 & $11 \cdot 1$ & $10 \cdot 1$ & 9.0 \\
\hline $18: 4 n-3$ & 0.1 & 0.3 & 0.4 & 0.6 & 0.7 & 0.1 & 0.3 & 0.5 & 1.0 \\
\hline $20: 4 n-3$ & 0.0 & 0.1 & $0 \cdot 1$ & 0.1 & 0.2 & 0.0 & 0.1 & $0 \cdot 1$ & 0.3 \\
\hline $20: 5 n-3$ & 0.7 & 1.4 & 1.8 & $2 \cdot 3$ & $2 \cdot 8$ & 0.6 & 1.4 & 2.4 & $4 \cdot 1$ \\
\hline $22: 5 n-3$ & 0.1 & 0.2 & 0.2 & 0.3 & 0.4 & 0.1 & 0.2 & 0.3 & 0.5 \\
\hline $22: 6 n-3$ & 0.7 & 1.3 & 1.6 & $2 \cdot 0$ & $2 \cdot 4$ & 0.7 & 1.3 & $2 \cdot 0$ & $3 \cdot 3$ \\
\hline Sum $n-3$ & $14 \cdot 8$ & $15 \cdot 4$ & $15 \cdot 7$ & $16 \cdot 1$ & $16 \cdot 7$ & 13.2 & 14.5 & $15 \cdot 5$ & 18.4 \\
\hline
\end{tabular}

period of $216 \mathrm{~d}$ (Fig. 1(a)). The biomass in each tank was then split into two new $3 \mathrm{~m}$ tanks and continued with the same diets. The temperature in one tank on each diet was continued at $12^{\circ} \mathrm{C}\left(11.8(\operatorname{SEM} 0.02)^{\circ} \mathrm{C}\right)$, whereas the other during a $6 \mathrm{~d}$ period (Fig. 1(a)) was gradually decreased to $6^{\circ} \mathrm{C}(6.5$ (SEM $0 \cdot 02)^{\circ} \mathrm{C}$ ). At the start of the temperature trial the number of fish in each tank was 48-57, and the mean BW was 1442 (SEM 19) $\mathrm{g}(n$ 264) and 1458 (SEM 19) $\mathrm{g}(n$ 268) in the 12 and $6^{\circ} \mathrm{C}$ groups, respectively. The fish were fed the experimental diets (Table 1) until they reached an average BW of $3 \mathrm{~kg}$ (Fig. 1(a)), i.e. for 142 and $202 \mathrm{~d}$ at 12 and $6^{\circ} \mathrm{C}$, respectively. Due to lower growth than expected at $12^{\circ} \mathrm{C}$ in trial 1 and a positive correlation between growth and dietary EPA + DHA content, it was decided to repeat this part with a wider range of dietary EPA + DHA levels.
In trial 2, Atlantic salmon ( $n$ 1200, BW $440 \mathrm{~g})$ were fed a diet low in EPA + DHA (3\% of total FA, Supplementary Table S5) during a run-in period of $158 \mathrm{~d}$ to bring the level of EPA and DHA in the fish down to a common low start level. The fish were first kept in one $8 \mathrm{~m}$ tank (75000 litres) with seawater at $8^{\circ} \mathrm{C}$ for $112 \mathrm{~d}$ before the fish were moved to four $3 \mathrm{~m}$ tanks and the water temperature gradually increased to $12^{\circ} \mathrm{C}$ to acclimatise the fish to the trial conditions (Fig. 1(b)). For the trial, a total of 560 fish with a mean BW of 1439 (SEM 9) g were distributed equally in eight tanks (seventy fish per $3 \mathrm{~m}$ tank) supplied with flow-through seawater at 11.8 (sEM $0 \cdot 01)^{\circ} \mathrm{C}$ and photoperiod of $24 \mathrm{~h}$ light. Duplicate tanks (n 2) of Atlantic salmon were fed the experimental diets with graded levels of EPA + DHA from 1.3 to $7.4 \%$ of total FA (Tables 1 and 2) for $151 \mathrm{~d}$ (Fig. 1(b)).

(a)

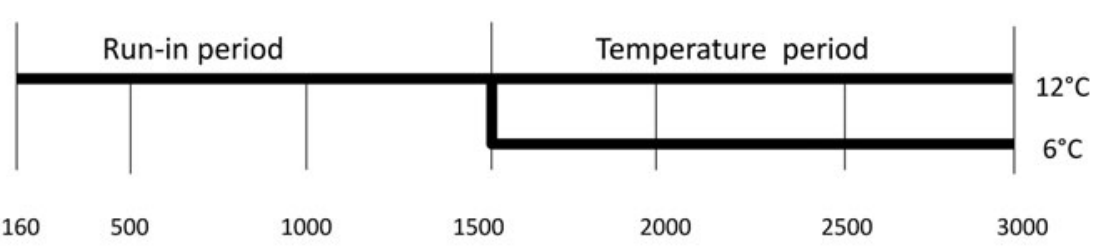

(b) $\begin{array}{lllllll}\begin{array}{l}\text { Fish } \\ \text { weight, g }\end{array} & 160 & 500 & 1000 & 1500 & 2000 & 2500\end{array}$

\begin{tabular}{|c|c|c|}
\hline \multicolumn{2}{|c|}{ Run-in period } & Trial period \\
\hline $8^{\circ} \mathrm{C}$ & $8 \rightarrow 12^{\circ} \mathrm{C}$ & $12^{\circ} \mathrm{C}$ \\
\hline $112 \mathrm{~d}$ & $46 \mathrm{~d}$ & $151 \mathrm{~d}$ \\
$1 \times 8 \mathrm{~m}$ & $4 \times 3 \mathrm{~m}$ & $8 \times 3 \mathrm{~m}$ \\
\hline
\end{tabular}

Fish

weight, g 440

1450

3000

Fig. 1. Outline of temperature regimens and corresponding developments in fish weight, in trial 1 (a) and trial 2 (b). In trial 1 fish were kept at $12^{\circ} \mathrm{C}$ during the run-in period of $216 \mathrm{~d}$ before tanks were split and continued at 12 and $6^{\circ} \mathrm{C}$ for 142 and $202 \mathrm{~d}$, respectively. In trial 2 the run-in period consisted of $112 \mathrm{~d}$ at $8^{\circ} \mathrm{C}$ and $46 \mathrm{~d}$ of acclimatisation to experimental tanks and temperatures. The trial period lasted for $151 \mathrm{~d}$ at $12^{\circ} \mathrm{C}$. 
Both trials were performed at Skretting ARC Fish Trial Station (Lerang, Norway) and were conducted according to the guidelines of the Norwegian State Commission for Laboratory Animals, at an approved facility for research with animals and were approved by the responsible person for animal ethics at the facility. Diets were distributed in slight excess of expected feed intake using automatic feeders (Betten S1 mini; Betten Maskinstasjon). All tanks were equipped with waste feed collectors for the control of daily feed intake. Standard husbandry procedures at the research station were applied.

\section{Sampling and biometric indices}

All experimental diets were sampled and stored at $-20^{\circ} \mathrm{C}$ until analysis. Salmon were anaesthetised in a bath with tricaine methanesulfonate (FINQUEL MS-222, $7 \mathrm{~g} / \mathrm{l}$ ) before registration of RFID tag, BW and body length of all individual fish. Sampled fish were killed by an overdose of anaesthesia in a separate tank. Ten fish per tank were sampled for whole-body analyses of proximate and FA composition at the start and end of the temperature period in trial 1 whereas, in trial 2 , ten fish were sampled from the start population and five fish from each tank at the end. The fish were opened and the weights of liver, gonad (if present) and gutted fish were registered before making pooled samples of the whole fish from each tank. Sexually mature fish were not included in the whole-body samples. In trial 1 individual fillet samples were collected at every $500 \mathrm{~g}$ growth interval for analyses of proximate and FA composition. Six fish were sampled from the start population and from each tank before the temperature period (about $1500 \mathrm{~g} \mathrm{BW}, n$ 30). Eight fish per tank ( $n$ 80) were sampled at the end of the trial while three fish per tank were sampled at the intermediate sampling points (BW: 500, 1000, 2000 and $2500 \mathrm{~g}$ ) for fillet composition. Similarly in trial 2 , individual fillets were obtained from sixteen fish at the start and from four and six fish per tank at the intermediate and final samplings, respectively. Weights of liver, gonads and gutted fish were recorded for these fish. Condition factor was determined in all fish, and liver index (hepatosomatic index; \%), gonadosomatic index (\%) and dress-out percentage were determined in all sampled fish ( $>20$ fish per tank) at the end of both trials. Liver was dissected from eight and six fish per tank at the end of trials 1 and 2, respectively. A small piece was immediately frozen in liquid $\mathrm{N}_{2}$ and stored at $-80^{\circ} \mathrm{C}$ for gene expression analysis.

\section{Proximate composition analyses}

Diets, whole fish and fillets were analysed for content of DM, crude protein and total lipid using standard laboratory methods. DM and ash were measured gravimetrically after drying at $103^{\circ} \mathrm{C}$ for $24 \mathrm{~h}$ and after flame combustion at $550^{\circ} \mathrm{C}$ for $16-18 \mathrm{~h}$, respectively ${ }^{(28)}$. Total $\mathrm{N}$ was determined using the Kjeldahl method and crude protein calculated as $\mathrm{N} \times$ $6 \cdot 25^{(29)}$. Total fat in feeds was measured gravimetrically after acid hydrolysis and extraction with diethyl ether ${ }^{(30)}$, whereas total fat in the fish samples was determined gravimetrically according to the $\mathrm{AOCS}^{(31)}$ after extraction with dichloromethane instead of petroleum ether in a Soxtec apparatus (Soxtec Auto Avanti).

\section{Fatty acid analysis}

FA analysis was performed after methylation of the FA in methanolic $\mathrm{HCl}$ and extraction in hexane ${ }^{(32)}$. The FA composition was determined after separation of the methyl esters in a gas chromatograph (Thermo Trace GC with Triplus autosampler; Thermo Scientific), equipped with a cold on-column injector $\left(90^{\circ} \mathrm{C}\right.$ for $2 \mathrm{~min}, 30^{\circ} \mathrm{C} / \mathrm{min}$ to $150^{\circ} \mathrm{C}, 3^{\circ} \mathrm{C} / \mathrm{min}$ to $225^{\circ} \mathrm{C}$, held for $5 \mathrm{~min}$ ), a Varian $25-\mathrm{m} \mathrm{CP}$ Wax 52 capillary column (internal diameter $0.25 \mathrm{~mm}$, film thickness $0.20 \mu \mathrm{m}$ ), a flame ionisation detector, and $\mathrm{He}$ as the carrier gas. The FA were identified by retention time using standard mixtures of methyl esters (Nu-Chek, Elyian), and the FA composition (percentage of total FA) was determined. All samples were integrated using the software Chromeleon ${ }^{\circledR}$ version 6.8 connected to the GC. Amount of FA per $g$ sample was calculated using 23 : 0 methyl-ester as internal standard. Data on wholefish FA composition are presented as percentage of total FA, to facilitate comparison between samplings and temperatures when the fish differ in total lipid content. For retention calculations the $\mathrm{mg} / \mathrm{g}$ data are used, as these were considered more reliable than combining the percentage of total FA data with lipid content determined gravimetrically, the latter being a relatively crude method with higher variability. The data as percentage of total FA are given in the Results section, while the $\mathrm{mg} / \mathrm{g}$ data are provided as Supplementary material (Supplementary Tables S9-S11).

\section{Gene expression analyses}

RNA purification, including homogenisation, DNase treatment and assessment of quantity and quality were done as described in Sissener et al. ${ }^{(33)}$. Average RNA integrity number for a selection of twelve samples in trial 1 was 8.2 (SD 0.2 ) and 9.5 $\left(\mathrm{SD} 0 \cdot 2\right.$ ) at 12 and $6^{\circ} \mathrm{C}$, respectively, and $9 \cdot 1$ (SD 0.5) in trial 2.

Reverse transcription was performed on a GeneAmp PCR 9700 (Applied Biosystems, AB) using the TaqMan ${ }^{\circledR}$ reverse transcriptase kit with oligo(dT) primers (Applied Biosystems). Primer sequences for $\Delta 5$ - and $\Delta 6$-desaturase and the reference genes $\beta$-actin and EF1 $\alpha$ have already been published elsewhere $^{(34,35)}$. Samples were run in duplicate (500 ng, $\pm 5 \%$ ), in addition to a six-point dilution curve in triplicate (1000 to $31.25 \mathrm{ng}$ ), non-template and non-amplification controls. Real-time PCR amplification and analysis were performed on a LightCycler 480 Real-time PCR system (Roche Applied Science) with SYBR ${ }^{\circledR}$ Green I Mastermix (Roche Applied Science). Pipetting of plates was done using a Biomek $® 3000$ Laboratory automation workstation (Beckman Coulter). Thermal cycling was done for forty-five cycles of $10 \mathrm{~s}$ at each of 95,60 and $72{ }^{\circ} \mathrm{C}$ (basic program from Roche), followed by melting analysis to confirm that only one product was present.

Cycle threshold $\left(C_{t}\right)$ values were calculated using the second maximum derivative method in the Lightcycler ${ }^{\circledR}$ software. Amplification efficiency was determined using the dilution 
curves with the formula $E=10^{\wedge}(-1 /$ slope $)$, with the slope of the linear curve of $C_{t}$ values plotted against the $\log$-dilution ${ }^{(36)}$. Data analysis was conducted with GenEx 4.3.5 (MultiD Analyses AB), including efficiency correction, normalisation with both reference genes and averaging of technical replicates.

\section{Calculations}

Specific growth rate $(\mathrm{SGR}, \% / \mathrm{d})=100 \times\left(\ln W_{\mathrm{f}}-\ln W_{\mathrm{i}}\right) / t$, where $W$ is final and initial $\mathrm{BW}$ and $t$ is number of days between $W_{\mathrm{i}}$ and $W_{\mathrm{f}}$.

Thermal growth coefficient $($ TGC $)=1000 \times\left(W_{\mathrm{f}}^{0.333}-\right.$ $\left.W_{\mathrm{i}}^{0.333}\right) /{ }^{\circ} \mathrm{C} \times t$,

where $W$ is final and initial $\mathrm{BW}, t$ is number of days between $W_{\mathrm{i}}$ and $W_{\mathrm{f}}$ and ${ }^{\circ} \mathrm{C}$ is mean temperature.

Feed conversation ratio $(\mathrm{FCR})=$ feed eaten $(\mathrm{g}) / \mathrm{BW}$ gain $(\mathrm{g})$. Condition factor $=$ whole $\mathrm{BW}(\mathrm{g}) /(\text { body length }(\mathrm{cm}))^{3}$.

Organ index $=100 \times$ weight organ $(\mathrm{g}) /$ fish whole $\mathrm{BW}(\mathrm{g})$.

Retention of FA $(\%)=100 \times\left(\left(W_{\mathrm{f}} \mathrm{FA}_{\mathrm{f}}\right)-\left(W_{\mathrm{i}} \mathrm{FA}_{\mathrm{i}}\right)\right) /\left(W_{\mathrm{f}}-\right.$ $\left.W_{\mathrm{i}}\right) \times$ FCR $F A_{\mathrm{d}}$,

where $W_{\mathrm{i}}$ and $W_{\mathrm{f}}$ are initial and final $\mathrm{BW}$ of individual fish, $F A_{i}, F A_{f}$ and $F A_{d}$ are the initial and final $F A$ content in $\mathrm{mg} / \mathrm{g}$ in fish and diet, and FCR is FCR per tank.

\section{Statistics}

For measuring statistical differences between the dietary groups for FA analysis, growth parameters and body indices, regression analysis was conducted on tank means (MATLAB and Statistics Toolbox Release 2013a; The MathWorks, Inc.) and one-way ANOVA was done on pseudoreplicates from the same tanks in trial $1(P<0.05)$ (MATLAB and Statistics Toolbox Release 2013a and GraphPad Prism5; GraphPad Software, Inc.), followed by post hoc Tukey's multiple comparison test. Hence, ANOVA results from trial 1 must be treated with caution due to the inability to distinguish between diet effects and tank effects in this statistical analysis. These results must be interpreted together with results from regression analysis and results from trial 2 to get the full picture of which effects are likely to be biologically meaningful. In trial 2 , nested ANOVA was conducted on the performance data to account for potential tank effects (diet as fixed factor and tank as random factor). The parameters SGR, TGC and BW gain, which are often calculated on a tank basis in fish trials, were calculated for individual fish as these were pit tagged and we therefore had both initial and final BW for the same fish. Results are presented as means with their standard errors unless otherwise stated.

\section{Results}

\section{Diets}

Proximate composition was similar for all $8 \mathrm{~mm}$ diets (Table 1 and Supplementary Table S5). The analysed content of EPA + DHA in the diets in trial 1 was slightly higher than the formulated levels $(1-5 \%) ; 1.4,2 \cdot 7,3 \cdot 4,4.4$ and $5 \cdot 2 \%$ of total FA, respectively (Table 2). Analysed EPA + DHA levels in trial 2 diets were $1 \cdot 3,2 \cdot 7,4.4$ and $7 \cdot 4 \%$ of total FA. For the remainder of the present article, the fish groups will be referred to by the number of the trial followed by the percentage of EPA + DHA in the diet, i.e. 1:1.4 refers to the fish in trial 1 fed $1.4 \% \mathrm{EPA}+\mathrm{DHA}$ of total dietary FA.

\section{Fish performance}

Mortality was low and independent of diet in both trials: $0.2 \%$ during the temperature period in trial 1 and $0.4 \%$ in trial 2. During the $216 \mathrm{~d}$ run-in period in trial 1 , the fish grew from an average BW of 162 (SEM 0.9) g (n 750) to 1433 (sEM 13) $\mathrm{g}(n$ 649). The growth, expressed as gain and TGC, during this period was similar in diet groups 1:1.4 and 1:5.2 and slightly better in fish fed diets 1:2.7 and 1:3.4 with no linear regression $(P=0.97)$ to dietary EPA + DHA content (Table 3). Towards the end of the trial some fish started to develop gonads, resulting in reduced growth performance. This was confirmed using results for individual fish showing that all outliers in all groups were fish with low SGR $(<0 \cdot 35)$ and gonadosomatic index $>1 \%$ (data not shown). Thus, in order to get reliable results on dietary effects, further analyses were done using data from fish with $S G R \geq 0 \cdot 35$, which excluded fish with very low or negative growth in all groups. During the temperature period there were no significant differences in BW gain between groups at either temperature, but the regression between $\mathrm{BW}$ gain and dietary content of $\mathrm{EPA}+\mathrm{DHA}$ was significant at $12^{\circ} \mathrm{C}\left(\mathrm{R}^{2} 0.88, \beta 58\right.$, $P=0.02$ ) (Table 3). Fish fed the diet with the highest EPA + DHA content (diet 1:5.2) had higher TGC (ANOVA, $P<0.05)$ than fish fed diet 1:1.4 at both temperatures (Table 3). Linear regression between TGC and dietary EPA + DHA content was significant at $12^{\circ} \mathrm{C}$, but not at $6^{\circ} \mathrm{C}$ (Table 3).

The mean BW gain in trial 2 varied from 1804 (sEM 51) $\mathrm{g}$ ( $n$ 120) in diet group 2:2.7 to 2151 (SEM 56) g ( $n$ 120) in diet group 2:7.4 during the experimental period of $151 \mathrm{~d}$ (Table 4). BW gain in fish fed the two lowest dietary EPA + DHA contents (2:1.3 and 2:2.7) was significantly lower (nested ANOVA, $P<0 \cdot 05)$ than in fish fed the diets with the highest EPA + DHA contents (2:4.4 and 2:7.4) (Table 4). The average TGC in trial 2 was 2.06 (SEM 0.06) ( $n$ 8), and linear regressions were significant between dietary EPA + DHA content and BW gain $(P=0.02)$ and TGC $(P=0.02)$. As for mean $\mathrm{BW}$ gain, fish fed the diets with the two highest EPA + DHA contents had significantly higher $(P<0.05)$ TGC than fish fed the two lowest EPA + DHA levels (Table 4).

Fish growth in both trials was also assessed as relative growth index (RGI), based on Skretting's growth model (RGI calculator v7, Skretting; http://www.skretting.com/ nb-NO/forskning--innovasjon/innovasjoner/aquasim1/), predicting growth as a function of fish size, temperature, feed intake, feed type and season. An RGI of $100 \%$ in this model will be an average good growth under normal farming conditions of Atlantic salmon with normal health. The RGI for fish in trial 1 ranged from 110 to $122 \%$ at $6^{\circ} \mathrm{C}$ and 77 to $88 \%$ at $12^{\circ} \mathrm{C}$, and from 90 to $100 \%$ in trial 2 . The decision to run the second trial was based on low RGI at $12^{\circ} \mathrm{C}$ in the first trial. 
Table 3. Performance and feed efficiency in Atlantic salmon fed dietary EPA + DHA from 1.4 to $5.2 \%$ of total fatty acids for 142 and $202 \mathrm{~d}$ at 12 and $6^{\circ} \mathrm{C}$, respectively $\dagger$ (Mean values with their standard errors)

\begin{tabular}{|c|c|c|c|c|c|c|c|c|c|c|c|c|}
\hline & \multicolumn{2}{|c|}{ Diet 1:1.4 } & \multicolumn{2}{|c|}{ Diet $1: 2 \cdot 7$} & \multicolumn{2}{|c|}{ Diet 1:3.4 } & \multicolumn{2}{|c|}{ Diet $1: 4.3$} & \multicolumn{2}{|c|}{ Diet 1:5.2 } & \multirow[b]{2}{*}{ Regression linear } & \multirow[b]{2}{*}{ ANOVA } \\
\hline & Mean & SEM & Mean & SEM & Mean & SEM & Mean & SEM & Mean & SEM & & \\
\hline \multicolumn{13}{|l|}{ Run-in period } \\
\hline Initial weight (g) & 161 & 2 & 163 & 2 & 161 & 2 & 163 & 2 & 163 & 2 & & NS \\
\hline Final weight (g) & $1360^{a}$ & 25 & $1480^{\mathrm{b}}$ & 30 & $1478^{\mathrm{b}}$ & 30 & $1467^{\mathrm{a}, \mathrm{b}}$ & 29 & $1379^{\mathrm{a}, \mathrm{b}}$ & 27 & NS & $\star *$ \\
\hline Gain $(\mathrm{g})$ & $1201^{a}$ & 27 & $1320^{\mathrm{b}}$ & 29 & $1315^{\mathrm{b}}$ & 29 & $1302^{a, b}$ & 28 & $1207^{a}$ & 27 & NS & ** \\
\hline TGC & $2 \cdot 16^{\mathrm{a}, \mathrm{b}}$ & 0.03 & $2 \cdot 27^{\mathrm{b}}$ & 0.03 & $2 \cdot 21^{\mathrm{b}}$ & 0.03 & $2 \cdot 20^{\mathrm{a}, \mathrm{b}}$ & 0.03 & $2 \cdot 16^{\mathrm{a}}$ & 0.03 & NS & ** \\
\hline \multicolumn{13}{|l|}{$12^{\circ} \mathrm{C}$} \\
\hline Initial weight (g) & 1369 & 51 & 1518 & 47 & 1485 & 50 & 1476 & 56 & 1412 & 52 & NS & NS \\
\hline Final weight (g) & 2780 & 132 & 3085 & 95 & 3056 & 115 & 3057 & 137 & 3074 & 124 & NS & NS \\
\hline Gain (g) & 1410 & 87 & 1567 & 75 & 1571 & 70 & 1581 & 88 & 1662 & 80 & $R^{2}=0.88, \beta=58^{*}$ & NS \\
\hline Number of fish & 32 & & 40 & & 33 & & 34 & & 41 & & & \\
\hline TGC & $1 \cdot 72^{\mathrm{a}}$ & 0.07 & $1 \cdot 80^{\mathrm{a}, \mathrm{b}}$ & 0.05 & $1.83^{\mathrm{a}, \mathrm{b}}$ & 0.04 & $1.84^{\mathrm{a}, \mathrm{b}}$ & 0.06 & $1.95^{\mathrm{b}}$ & 0.06 & $R^{2}=0.92, \beta=0.055^{\star \star}$ & * \\
\hline Feed intake‡ (g/fish) & 1475 & & 1502 & & 1573 & & 1599 & & 1610 & & & \\
\hline FCR & 1.02 & & 0.98 & & 1.04 & & 1.02 & & 0.93 & & NS & \\
\hline \multicolumn{13}{|l|}{$6^{\circ} \mathrm{C}$} \\
\hline Initial weight (g) & $1376^{\mathrm{a}, \mathrm{b}}$ & 54 & $1494^{\mathrm{a}, \mathrm{b}}$ & 48 & $1567^{\mathrm{a}}$ & 58 & $1470^{\mathrm{a}, \mathrm{b}}$ & 62 & $1358^{\mathrm{b}}$ & 44 & NS & * \\
\hline Final weight $(\mathrm{g})$ & 3249 & 121 & 3764 & 123 & 3833 & 165 & 3639 & 155 & 3556 & 134 & NS & NS \\
\hline Gain $(g)$ & 1873 & 76 & 2269 & 82 & 2266 & 113 & 2169 & 103 & 2198 & 95 & NS & NS $(P=0.055)$ \\
\hline Number of fish & 27 & & 34 & & 32 & & 34 & & 44 & & & \\
\hline TGC & $2.79^{a}$ & 0.06 & $3.11^{\mathrm{b}}$ & 0.06 & $3.03^{\mathrm{a}, \mathrm{b}}$ & 0.08 & $3 \cdot 03^{\mathrm{a}, \mathrm{b}}$ & 0.07 & $3 \cdot 14^{\mathrm{b}}$ & 0.07 & NS & * \\
\hline Feed intake $\ddagger$ (g/fish) & 2016 & & 2135 & & 2271 & & 2082 & & 1999 & & & \\
\hline FCR $\ddagger$ & 1.05 & & 0.96 & & 0.98 & & 0.98 & & 0.91 & & NS & \\
\hline
\end{tabular}

TGC, thermal growth coefficient; FCR, feed conversion ratio.

a,b Mean values within a row with unlike superscript letters were significantly different $(P \leq 0.05)$.

${ }^{*} P \leq 0.05,{ }^{*} P \leq 0.01$.

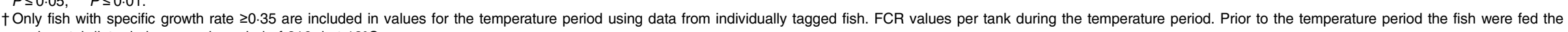
experimental diets during a run-in period of $216 \mathrm{~d}$ at $12^{\circ} \mathrm{C}$

‡ Calculated per tank including all fish. 
Table 4. Fish performance and feed efficiency in Atlantic salmon fed dietary EPA + DHA from 1.3 to $7.4 \%$ of total fatty acids for $151 \mathrm{~d}$ at $12^{\circ} \mathrm{C}+$ (Mean values with their standard errors)

\begin{tabular}{|c|c|c|c|c|c|c|c|c|c|c|}
\hline & \multicolumn{2}{|c|}{ Diet 2:1.3 } & \multicolumn{2}{|c|}{ Diet 2:2.7 } & \multicolumn{2}{|c|}{ Diet 2:4.4 } & \multicolumn{2}{|c|}{ Diet 2:7.4 } & \multirow[b]{2}{*}{ Regression linear } & \multirow[b]{2}{*}{ Nested ANOVA } \\
\hline & Mean & SEM & Mean & SEM & Mean & SEM & Mean & SEM & & \\
\hline Initial weight (g) & 1436 & 18 & 1447 & 18 & 1434 & 18 & 1434 & 18 & NS & NS \\
\hline Number of fish & 140 & & 140 & & 139 & & 139 & & & \\
\hline Final weight (g) & $3252^{a}$ & 62 & $3243^{a}$ & 59 & $3420^{a, b}$ & 57 & $3597^{\mathrm{b}}$ & 64 & $R^{2}=0.56, \beta=62^{*}$ & * \\
\hline Number of fish & 122 & & 120 & & 117 & & 120 & & & \\
\hline Gain $(g)$ & $1806^{a}$ & 54 & $1804^{\mathrm{a}}$ & 51 & $2009^{b}$ & 45 & $2151^{\mathrm{b}}$ & 56 & $R^{2}=0.60, \beta=62^{*}$ & * \\
\hline TGC & $1.93^{\mathrm{a}}$ & 0.05 & $1.94^{\mathrm{a}}$ & 0.04 & $2 \cdot 13^{\mathrm{b}}$ & 0.04 & $2 \cdot 23^{b}$ & 0.05 & $R^{2}=0.66, \beta=0.054^{\star}$ & * \\
\hline FCR & & & & & & & & & $R^{2}=0.67, \beta=-0.014^{*}$ & \\
\hline Tank 1 & $1 \cdot 16$ & & $1 \cdot 16$ & & 1.08 & & 1.05 & & & \\
\hline Tank 2 & $1 \cdot 10$ & & $1 \cdot 10$ & & 1.08 & & 1.05 & & & \\
\hline
\end{tabular}

TGC, thermal growth coefficient; FCR, feed conversion ratio.

a,b Mean values within a row with unlike superscript letters were significantly different $(P \leq 0.05)$.

${ }^{*} P \leq 0.05$.

† Nested ANOVA was conducted using data from individually tagged fish followed by Tukey's honestly significant difference post hoc test and showed no significant differences between replicate tanks. Results are presented as mean values with their standard errors of individual fish per diet. FCR values are for each of the two tanks. The regression analyses were conducted on all eight tank means.

The FCR in trial 1 varied between 0.93 and 1.04 at $12^{\circ} \mathrm{C}$ and between 0.91 and 1.05 at $6^{\circ} \mathrm{C}$ (Table 3). At both temperatures, FCR was lowest for diet 1:5.2, but regression to dietary EPA + DHA content was not significant $(P=0.38$ and $P=$ 0.07 at 12 and $6^{\circ} \mathrm{C}$, respectively). In trial 2 , FCR was significantly reduced with increasing dietary contents of EPA + DHA $\left(R^{2} 0 \cdot 67 ; P=0 \cdot 03\right)$ (Table 4).

\section{Biometric indices}

None of the biometric indices showed a significant doseresponse relationship with the amount of EPA + DHA in the diet $(P>0.05)$ (Supplementary Tables S6 and S7).

\section{Fish proximate and fatty acid composition}

Proximate composition of the whole body in both trials was not affected by dietary EPA + DHA content (Supplementary Table S8); neither was fillet proximate composition (data not shown). The FA composition in fillet was determined at every $500 \mathrm{~g}$ growth interval in trial 1 . As shown in Fig. 2, it took around $150 \mathrm{~d}$ before the fillet contents of EPA and DHA stabilised relative to diet. During this period the fish increased their BW nearly seven times. Whereas the content of EPA per diet group remained constant at 1.1 to $1.7 \%$ of total FA during the temperature trial, DHA continued to decrease and ended at 2.0 to $4.2 \%$ of total FA depending on dietary content, in diet groups $1: 1.4$ and 1:5.2, respectively. The diet-related changes in EPA and DHA content in fillet were not affected by temperature (Supplementary Table S9).

In trial 2, fillet content of EPA + DHA (percentage of total FA) was $4.8 \%$ at the start of the trial (after the run-in period) and ended at $3 \cdot 6,4 \cdot 1,5 \cdot 2$ and $6.6 \%$ in fish fed dietary levels of $1 \cdot 3, \quad 2 \cdot 7, \quad 4.4$ and $7.4 \%$ EPA + DHA of total FA (Supplementary Table S10). The FA composition in the whole body changed in a similar manner as the fillet composition during the trials (Tables 5 and 6). Both for EPA and DHA, there were gradients according to diet group, where fish receiving less in the diet also had a lower whole-body content. However, the differences in whole fish were smaller than the differences between the diets. In trial 1, DHA as percentage of total FA decreased in all diet groups during the temperature period, while EPA was more stable for each dietary group.

\section{Fatty acid retention}

Retention efficiency of dietary EPA and DHA was calculated using BW gain values for individual fish, FA contents in feeds and whole body expressed as $\mathrm{mg} / \mathrm{g}$ (Supplementary Tables S11-S13) and estimated feed intake using FCR per tank. In both trials, net production (retention efficiency values $>100$ $\%$ ) of DHA was found in all diet groups (Fig. 3). However, the DHA retention efficiency was fairly constant when dietary levels of EPA + DHA were 3-4\% of total FA and above, but increased sharply when dietary EPA + DHA levels decreased, reaching around $200 \%$ at the lowest dietary level. A similar response was also seen for EPA, but in contrast to DHA, net production of EPA was only observed at the lowest $\mathrm{EPA}+\mathrm{DHA}$ level. Temperature did not seem to affect retention efficiency of EPA and DHA in Atlantic salmon.

\section{Gene expression}

Significant linear regressions were seen both for $\Delta 5$-desaturase $\left(R^{2} 0.94, \beta-0.97, P=0.004\right)$ and $\Delta 6$-desaturase $\left(R^{2} 0 \cdot 80, \beta\right.$ $-0.92, P=0.025)$ at $6^{\circ} \mathrm{C}$, with expression decreasing with increasing dietary EPA + DHA (Supplementary Fig. S1). At $12^{\circ} \mathrm{C}$, despite a similar trend, linear regressions were not significant for the same genes, possibly due to high variation and high expression in some individuals in diet group 1:4.3. In trial 2, fish in diet groups $2: 1.3$ and $2: 2.7$ appeared to have higher expression of these two genes than fish in diet groups 1:4.4 and 2:7.4. However, there was large individual variation and these differences were not significant.

\section{Discussion}

EFA requirements in salmonids have been examined previously ${ }^{(4-6)}$. However, all these trials were performed in the freshwater stage, with low-fat diets and poor growth compared with 

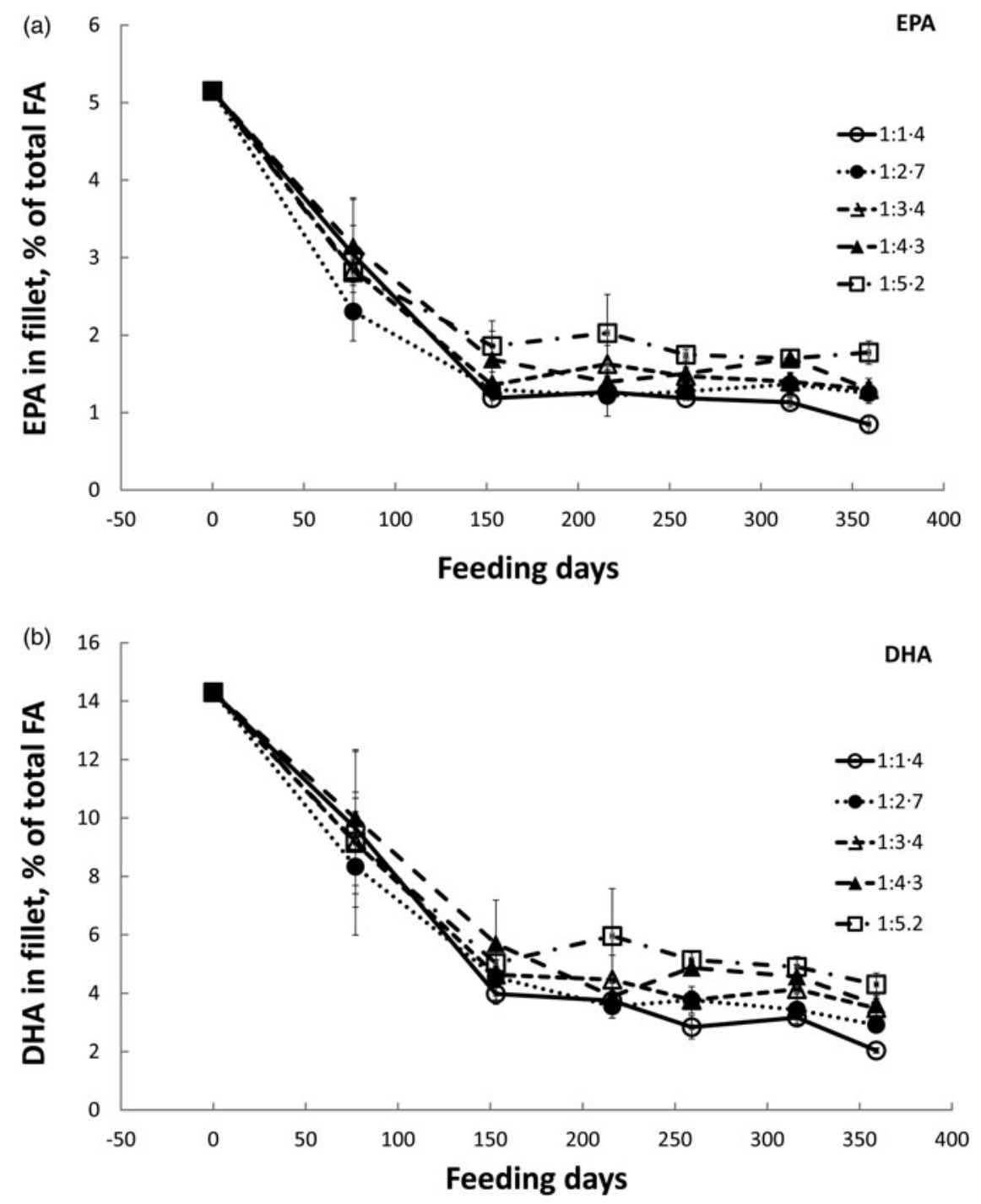

Fig. 2. Changes in fillet content (\% of total fatty acids (FA)) of EPA (a) and DHA (b) in Atlantic salmon fed dietary EPA + DHA levels from 1.4 to $5.2 \%$ of total FA for 216 and $142 \mathrm{~d}$ at $12^{\circ} \mathrm{C}$. Values are means of individual fish per tank $(n 3-8)$, with standard deviations represented by vertical bars.

common growth in commercial production. Consequently, $\mathrm{EPA}+\mathrm{DHA}$ requirements need to be reassessed in light of current production diets for salmonids, which have high levels of lipids and energy to support high growth rates ${ }^{(7)}$. The present trial used diets that were as close to a commercial high-energy diet as possible, while EPA + DHA should be the limiting factor in the diet. As $18: 3 n-3$ is present in most oil sources relevant for replacement of FO in commercial aquaculture, we chose to investigate the $\mathrm{EPA}+\mathrm{DHA}$ requirement in the presence of dietary $18: 3 n$-3. The VO mix used in this trial has not affected fish growth in previous trials ${ }^{(18,37)}$, and the observed effects can therefore be explained by the gradients in dietary EPA + DHA levels. There are indications that, at least for some species, EFA requirements might depend on lipid inclusion and hence be better expressed as percentage of the dietary $\mathrm{FA}^{(38,39)}$, which is done in this discussion.

The results from both trials and at both temperatures suggest a requirement for optimal growth between 2.7 and $3.4 \% \mathrm{EPA}$ + DHA of total FA. The fact that salmon perform better with dietary EPA + DHA compared with short-chain $n-3$ (LNA) has also been shown previously in the freshwater phase $^{(())}$. Few long-term trials in seawater have been conducted with salmon fed low EPA + DHA; however, in one trial of about 13-month duration in which EPA + DHA constituted only $2.7 \%$ of total FA in a VO diet, there was reduced growth compared with a FO diet in two out of three salmon strains tested $^{(40)}$. These data support our finding of $>2.7 \% \mathrm{EPA}+$ DHA being required for optimal long-term growth in seawater, but also suggest family differences in the ability to cope with low dietary EPA $+\mathrm{DHA}^{(40)}$. This could be related to family differences in the flesh content of EPA + DHA of fish fed the same $\operatorname{diets}^{(41)}$, and supports the usefulness of genetic selection for such traits. Another study feeding low EPA + DHA to postsmolt salmon was probably of too short duration to reveal significant growth differences, but noticeably fish fed 0.9 or $2.6 \%$ $\mathrm{EPA}+\mathrm{DHA}$ of total FA had (non-significantly) lower final BW than fish fed $4.1 \%$ or more ${ }^{(42)}$, correlating well with our results. The exact pathways affected by EFA deficiency that reduce growth in animals have not been determined ${ }^{(7)}$.

The fact that the dietary effect on growth in trial 1 only became apparent in the temperature period (about 1500$3000 \mathrm{~g}$ ), and not in the run-in period (about 160-1500 g), 
Table 5. Fatty acid composition (\% of total fatty acids) in the whole body of Atlantic salmon at the start and end of the temperature period in trial $1 \dagger$

\begin{tabular}{|c|c|c|c|c|c|c|c|c|c|c|c|c|c|c|c|c|c|}
\hline \multirow[b]{2}{*}{ Diet... } & \multicolumn{5}{|c|}{ Start 12 and $6^{\circ} \mathrm{C}$} & \multicolumn{5}{|c|}{ Final at $12^{\circ} \mathrm{C}$} & \multicolumn{5}{|c|}{ Final at $6^{\circ} \mathrm{C}$} & \multicolumn{2}{|c|}{ Regression } \\
\hline & $1: 1.4$ & $1: 2 \cdot 7$ & $1: 3.4$ & $1: 4 \cdot 3$ & $1: 5 \cdot 2$ & $1: 1.4$ & $1: 2 \cdot 7$ & $1: 3 \cdot 4$ & $1: 4 \cdot 3$ & $1: 5 \cdot 2$ & $1: 1.4$ & $1: 2 \cdot 7$ & $1: 3.4$ & $1: 4 \cdot 3$ & $1: 5 \cdot 2$ & $12^{\circ} \mathrm{C}$ & $6^{\circ} \mathrm{C}$ \\
\hline \multicolumn{18}{|l|}{ Fatty acids } \\
\hline \multicolumn{18}{|l|}{ Saturates } \\
\hline $14: 0$ & 1.0 & 1.3 & 1.5 & 1.7 & $2 \cdot 0$ & 0.7 & $1 \cdot 1$ & 1.3 & 1.6 & 1.9 & 0.7 & $1 \cdot 1$ & 1.4 & 1.6 & 1.9 & 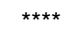 & $* \star \star$ \\
\hline $16: 0$ & $13 \cdot 2$ & $13 \cdot 6$ & 13.5 & 13.4 & $13 \cdot 1$ & 12.5 & $12 \cdot 9$ & $13 \cdot 1$ & $12 \cdot 9$ & 13.2 & $12 \cdot 1$ & $12 \cdot 3$ & 12.5 & $12 \cdot 4$ & 12.5 & NS & NS \\
\hline $18: 0$ & $3 \cdot 1$ & $3 \cdot 2$ & 3.0 & 3.0 & 2.8 & 3.2 & $3 \cdot 1$ & $3 \cdot 1$ & 3.0 & 3.0 & 3.1 & $3 \cdot 1$ & 3.1 & $2 \cdot 7$ & $2 \cdot 9$ & $\star \star *$ & NS \\
\hline Total saturates & $17 \cdot 8$ & $18 \cdot 7$ & 18.6 & $18 \cdot 8$ & 18.7 & $17 \cdot 1$ & $18 \cdot 0$ & 18.4 & 18.4 & 19.0 & $16 \cdot 6$ & $17 \cdot 1$ & $17 \cdot 7$ & 17.4 & $18 \cdot 1$ & ** & NS \\
\hline \multicolumn{18}{|l|}{ Monoenes } \\
\hline $16: 1 n-7 / 9$ & 1.3 & 1.6 & 1.9 & 2.0 & 2.4 & 1.0 & 1.5 & 1.7 & 1.9 & $2 \cdot 3$ & 1.2 & 1.7 & 1.9 & $2 \cdot 2$ & 2.6 & $\star \star \star *$ & *** \\
\hline $18: 1 n-9 / 7$ & 41.8 & 39.5 & 38.7 & 38.7 & $36 \cdot 6$ & $42 \cdot 8$ & $41 \cdot 1$ & $40 \cdot 1$ & 38.6 & 37.3 & 44.1 & $42 \cdot 7$ & $41 \cdot 1$ & 39.9 & 38.2 & 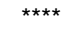 & *** \\
\hline $20: 1 n-9$ & $2 \cdot 1$ & $2 \cdot 2$ & 2.5 & 2.6 & $2 \cdot 7$ & $2 \cdot 3$ & $2 \cdot 7$ & $2 \cdot 9$ & 3.1 & 3.3 & $2 \cdot 3$ & $2 \cdot 7$ & 3.0 & 3.2 & 3.3 & 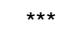 & 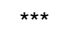 \\
\hline $22: 1 n-11 / 9$ & 0.9 & 1.1 & 1.3 & 1.5 & 1.7 & 0.8 & 1.2 & 1.5 & 1.7 & $2 \cdot 1$ & 0.7 & 1.1 & 1.4 & 1.6 & 2.0 & *** & * \\
\hline $\begin{array}{l}\text { Total monoenes } \\
n-6 \text { Fatty acids }\end{array}$ & $46 \cdot 4$ & $44 \cdot 8$ & $44 \cdot 7$ & $45 \cdot 3$ & 43.9 & $47 \cdot 3$ & $46 \cdot 9$ & $46 \cdot 7$ & $45 \cdot 9$ & $45 \cdot 7$ & $48 \cdot 7$ & 48.5 & $47 \cdot 8$ & $47 \cdot 3$ & $46 \cdot 5$ & ** & $* *$ \\
\hline $18: 2 n-6$ & $13 \cdot 1$ & $13 \cdot 0$ & 12.5 & $12 \cdot 4$ & $12 \cdot 3$ & 12.9 & $12 \cdot 3$ & $12 \cdot 3$ & 11.9 & 11.5 & 13.2 & $13 \cdot 0$ & $12 \cdot 7$ & 12.5 & $12 \cdot 0$ & $\star *$ & $\star *$ \\
\hline $20: 4 n-6$ & 0.4 & 0.3 & 0.3 & 0.3 & 0.3 & 0.2 & 0.2 & 0.2 & 0.2 & 0.2 & 0.3 & 0.2 & 0.2 & 0.2 & 0.2 & & NS \\
\hline Total $n-6$ & $15 \cdot 9$ & $15 \cdot 4$ & $14 \cdot 8$ & 14.4 & $14 \cdot 3$ & $15 \cdot 2$ & 14.5 & 14.2 & 13.7 & 13.2 & $15 \cdot 9$ & $15 \cdot 2$ & $14 \cdot 8$ & 14.5 & 14.0 & $\star \star * \star *$ & $\star * *$ \\
\hline \multicolumn{18}{|l|}{$n-3$ Fatty acids } \\
\hline $18: 3 n-3$ & 6.6 & $7 \cdot 1$ & 6.8 & 6.6 & 6.9 & 6.9 & $6 \cdot 8$ & $7 \cdot 0$ & $6 \cdot 8$ & 6.9 & $6 \cdot 7$ & 6.9 & $7 \cdot 0$ & $7 \cdot 1$ & $6 \cdot 8$ & NS & NS \\
\hline $18: 4 n-3$ & 2.2 & 1.6 & 1.5 & 1.5 & 1.3 & 1.8 & 1.3 & 1.3 & 1.2 & 1.1 & $2 \cdot 0$ & 1.5 & 1.3 & 1.1 & 1.1 & * & ** \\
\hline $20: 4 n-3$ & 0.8 & 0.8 & 0.8 & 0.8 & 0.8 & 0.8 & 0.8 & 0.7 & 0.8 & 0.8 & 0.9 & 0.9 & 0.9 & 0.9 & 0.9 & NS & \\
\hline $20: 5 n-3$ & 1.3 & 1.5 & 1.5 & 1.7 & $2 \cdot 1$ & 1.0 & 1.2 & 1.3 & 1.4 & 1.7 & 1.1 & 1.3 & 1.4 & 1.7 & 1.9 & ** & ** \\
\hline $22: 5 n-3$ & 0.5 & 0.6 & 0.6 & 0.7 & 0.8 & 0.4 & 0.5 & 0.5 & 0.6 & 0.7 & 0.5 & 0.6 & 0.6 & 0.7 & 0.8 & ** & ** \\
\hline $22: 6 n-3$ & 3.4 & 3.9 & 4.5 & 4.6 & $5 \cdot 2$ & $2 \cdot 1$ & 2.5 & 3.0 & 3.4 & 3.9 & 2.0 & 2.3 & 2.7 & 3.3 & 3.9 & 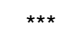 & $\star *$ \\
\hline Total $n-3$ & $15 \cdot 1$ & $15 \cdot 9$ & $16 \cdot 1$ & $16 \cdot 4$ & 17.5 & 13.2 & 13.5 & 14.3 & 14.7 & 15.6 & 13.3 & 13.9 & 14.4 & $15 \cdot 3$ & $15 \cdot 9$ & ** & $\star \star \star *$ \\
\hline
\end{tabular}

* $P \leq 0.05,{ }^{* *} P \leq 0.01,{ }^{* * *} P \leq 0.001,{ }^{* * * *} P \leq 0.0001$.

† Values represent pooled samples of ten fish per dietary treatment. 
Table 6. Fatty acid composition (\% of total fatty acids) in the whole body of Atlantic salmon at the start and end of trial $2 \nmid$

\begin{tabular}{|c|c|c|c|c|c|c|c|c|c|c|c|}
\hline \multirow{3}{*}{ Diet... } & & & \multicolumn{8}{|c|}{ Final } & \multirow[b]{3}{*}{ Regression } \\
\hline & \multicolumn{2}{|c|}{ Initial } & \multicolumn{2}{|c|}{$2: 1 \cdot 3$} & \multicolumn{2}{|c|}{$2: 2 \cdot 7$} & \multicolumn{2}{|c|}{$2: 4.4$} & \multicolumn{2}{|c|}{$2: 7 \cdot 4$} & \\
\hline & Mean & SEM & Tank 1 & Tank 2 & Tank 1 & Tank 2 & Tank 1 & Tank 2 & Tank 1 & Tank 2 & \\
\hline \multicolumn{12}{|l|}{ Fatty acids } \\
\hline \multicolumn{12}{|l|}{ Saturates } \\
\hline $14: 0$ & $1 \cdot 3$ & 0.0 & 1.0 & 0.9 & 1.3 & $1 \cdot 2$ & 1.5 & 1.5 & 2.4 & 2.4 & **** \\
\hline $16: 0$ & $12 \cdot 7$ & 0.1 & $13 \cdot 2$ & $13 \cdot 1$ & $13 \cdot 3$ & $13 \cdot 1$ & $13 \cdot 2$ & $13 \cdot 3$ & $13 \cdot 3$ & $13 \cdot 1$ & NS \\
\hline $18: 0$ & $3 \cdot 1$ & 0.1 & 2.9 & $2 \cdot 8$ & $2 \cdot 8$ & $2 \cdot 8$ & 2.9 & $2 \cdot 8$ & $2 \cdot 8$ & $2 \cdot 8$ & NS \\
\hline Total saturates & $18 \cdot 0$ & 0.2 & $17 \cdot 8$ & 17.5 & $18 \cdot 2$ & $17 \cdot 8$ & 18.5 & 18.4 & 19.4 & $19 \cdot 2$ & **** \\
\hline \multicolumn{12}{|l|}{ Monoenes } \\
\hline $16: 1 n-7 / 9$ & 1.6 & 0.0 & 1.1 & 1.15 & 1.4 & 1.5 & 1.8 & 1.8 & 2.5 & 2.5 & $* * \star *$ \\
\hline $18: 1 n-9 / 7$ & 40.4 & 0.1 & 41.7 & $42 \cdot 0$ & 40.5 & $41 \cdot 1$ & 39.0 & 39.4 & 35.4 & $35 \cdot 8$ & **** \\
\hline $20: 1 n-9$ & $2 \cdot 8$ & 0.0 & $2 \cdot 2$ & $2 \cdot 1$ & 2.5 & $2 \cdot 6$ & $2 \cdot 8$ & 2.9 & 3.15 & 3.2 & **** \\
\hline $22: 1 n-11 / 9$ & 1.5 & 0.1 & 0.9 & 0.9 & 1.2 & 1.2 & 1.6 & 1.5 & $2 \cdot 2$ & $2 \cdot 2$ & 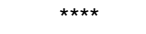 \\
\hline Total monoenes & $47 \cdot 1$ & 0.2 & $46 \cdot 4$ & 46.9 & $46 \cdot 2$ & 46.9 & 45.9 & $46 \cdot 3$ & 44.0 & 44.2 & 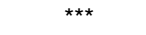 \\
\hline \multicolumn{12}{|l|}{$n-6$ Fatty acids } \\
\hline $18: 2 n-6$ & 13.3 & 0.1 & $14 \cdot 2$ & $14 \cdot 1$ & $13 \cdot 8$ & 13.6 & $13 \cdot 1$ & 12.95 & $12 \cdot 2$ & $12 \cdot 2$ & $* * * *$ \\
\hline $20: 4 n-6$ & 0.2 & 0.0 & 0.2 & 0.2 & 0.2 & 0.2 & 0.2 & 0.2 & 0.2 & 0.2 & ** \\
\hline Total $n-6$ & 15.4 & 0.1 & $16 \cdot 8$ & 16.5 & $16 \cdot 1$ & $15 \cdot 8$ & $15 \cdot 1$ & $15 \cdot 1$ & $14 \cdot 2$ & $14 \cdot 2$ & $* * * *$ \\
\hline \multicolumn{12}{|l|}{$n-3$ Fatty acids } \\
\hline $18: 3 n-3$ & $7 \cdot 0$ & 0.1 & $7 \cdot 7$ & $7 \cdot 8$ & 8.0 & $7 \cdot 7$ & $7 \cdot 7$ & 7.4 & 7.4 & 7.4 & * \\
\hline $18: 4 n-3$ & $1 \cdot 2$ & 0.1 & $1 \cdot 8$ & $1 \cdot 7$ & 1.5 & 1.3 & $1 \cdot 1$ & $1 \cdot 2$ & $1 \cdot 2$ & $1 \cdot 2$ & * \\
\hline $20: 4 n-3$ & 0.9 & 0.1 & 1.0 & 0.8 & 0.9 & 0.9 & 0.9 & 0.8 & 1.0 & 1.0 & NS \\
\hline $20: 5 n-3$ & 1.5 & 0.1 & $1 \cdot 3$ & $1 \cdot 3$ & 1.6 & 1.5 & $1 \cdot 8$ & $1 \cdot 7$ & 2.5 & $2 \cdot 4$ & **** \\
\hline $22: 5 n-3$ & 0.6 & 0.0 & 0.4 & 0.4 & 0.5 & 0.5 & 0.6 & 0.6 & 0.9 & 0.9 & **** \\
\hline $22: 6 n-3$ & $2 \cdot 9$ & 0.1 & $2 \cdot 4$ & 1.95 & $2 \cdot 8$ & $2 \cdot 4$ & $3 \cdot 3$ & $3 \cdot 1$ & $4 \cdot 2$ & $4 \cdot 3$ & 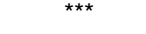 \\
\hline Total $n-3$ & 14.7 & 0.1 & $15 \cdot 1$ & 14.5 & $15 \cdot 9$ & 14.9 & $16 \cdot 1$ & 15.5 & $17 \cdot 9$ & $18 \cdot 0$ & 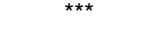 \\
\hline
\end{tabular}

${ }^{*} P \leq 0.05,{ }^{* *} P \leq 0.01,{ }^{* * *} P \leq 0.001,{ }^{* * *} P \leq 0.0001$.

$\dagger$ Values represent pooled samples of five fish per tank at final sampling and mean values with their standard errors for four pooled samples of five fish each at initial sampling.

clearly shows that long-term trials are necessary when determining FA requirements for optimal growth. A 9-fold increase in BW was achieved in the run-in period, and most feeding trials conducted with Atlantic salmon are shorter than this, even when effects of EFA have been studied ${ }^{(6,42)}$. A 7-fold increase in $\mathrm{BW}$ was required for muscle $\mathrm{FA}$ profile to stabilise relative to the diets, which proves the importance of feeding diets low in EPA + DHA for a long period of time to deplete body stores. For whole fish and muscle in salmon, there will be a high proportion of storage lipids (TAG) relative to PL, the latter being central components of cell membranes. While incorporation of dietary FA in TAG generally follows a dilution model, incorporation in PL is much more complex ${ }^{(43)}$, for instance in salmon fed an EFA-deficient diet, EFA in liver PL seemed to be conserved at the expense of $\mathrm{TAG}^{(44)}$. The FA composition of tissues does not only reflect diet, but is modified by processes such as preferential incorporation, $\beta$-oxidation, lipogenic activity and elongation and desaturation of $\mathrm{FA}^{(45)}$. Consequently, the FA profile in tissues other than muscle may take even longer to stabilise after a diet change. In Atlantic salmon fed a diet completely deficient of all $n-3$ and $n-6 \mathrm{FA}$, symptoms of deficiency only appeared in the fourth month of the study, while severe EFA deficiency did not develop ${ }^{(44)}$, further supporting the need for long-term trials.

Differences between fish reared at the two temperatures in SFA, MUFA and n-6 FA may indicate some thermal adaptation; however, no temperature effects were seen in EPA, DHA or total $n-3$ content in whole fish. If the main changes occur in cell membranes, these differences in the PL would probably be masked by the FA composition of the TAG which is present in much higher concentration than PL in whole fish and muscle. Hence, analyses of more PL-rich tissues could be more useful in this regard, which has been done by Sissener et al. ${ }^{(46)}$ using samples from these long-term trials. A study documenting $n-3$ content during the whole seawater production cycle in salmon fed the same feed in fish farms along the Norwegian coast concluded that temperature did not affect most FA, but had a slight effect on DHA which decreased in muscle with increasing temperature $^{(47)}$. An effect of temperature on DHA in muscle was not seen in our study. However, that study was conducted with dietary EPA + DHA at about 18-19\% of total FA, thus providing these $\mathrm{FA}$ in large excess of requirements, unlike the present study.

The very similar results seen for retention efficiency between the two temperatures in trial 1 and between the trials firmly support that net production (retention values $>100 \%$ ) of DHA occurs for all diet groups but increasingly so at the lowest dietary levels, and that DHA is retained to a higher degree than EPA. Higher retention for DHA than EPA is supported by previous feeding trials in Atlantic salmon ${ }^{(19,20)}$ and by a study on salmon hepatocytes ${ }^{(48)}$. Furthermore, many trials have observed that when DHA is reduced in the diet, the reduction observed in fish tissues is much lower than in the dietary lipids ${ }^{(11)}$, and that DHA is selectively deposited in muscle lipids regardless of concentration in the diet, while EPA and all other FA are increasingly used for metabolism as their dietary concentrations increase $\mathrm{e}^{(15)}$. All this highlights the important structural role of DHA in salmonids, however, not disregarding the functional importance of EPA. 

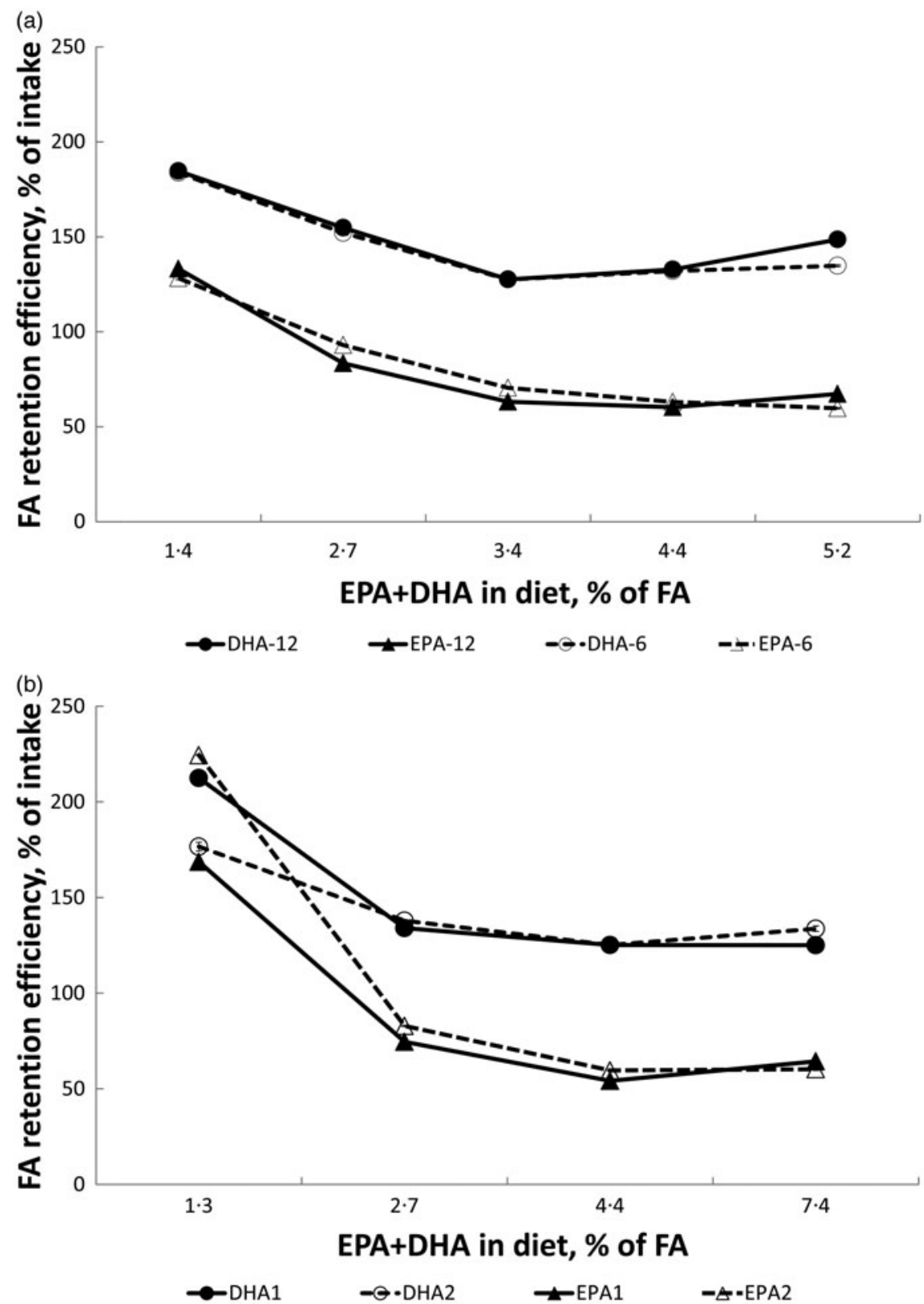

Fig. 3. Retention efficiency of EPA and DHA in Atlantic salmon fed dietary EPA + DHA levels from 1.4 to $5.2 \%$ of total fatty acids (FA) for 202 and $142 \mathrm{~d}$ at 6 and $12^{\circ} \mathrm{C}$, respectively (a) and 1.3 to $7.4 \%$ of total FA for $151 \mathrm{~d}$ at $12^{\circ} \mathrm{C}(\mathrm{b})$. Values are means per tank, with standard errors represented by vertical bars.

The retention efficiency of DHA did not seem to increase linearly with decreasing dietary content; however, there seemed to be a sharp increase in retention efficiency (close to $200 \%$ in both trials) at dietary levels below what was needed to sustain optimal growth. A sharp increase in DHA retention efficiency when diet levels are deficient has also been observed by others ${ }^{(42)}$. Reduced retention efficiency at increased dietary levels seems to be due to feedback inhibition by $n-3$ long-chain $\mathrm{FA}^{(49)}$, probably DHA rather than $\mathrm{EPA}^{(48)}$. Regulation of synthesis of long-chain $n-3 \mathrm{FA}$ in Atlantic salmon involves the modulation of gene expression of fatty acyl desaturases ${ }^{(35)}$. This was also observed in our experiment, with tendencies towards increased expression of both $\Delta 5$ - and $\Delta 6$-desaturase with increasing retention efficiency in the groups fed low dietary EPA + DHA. Effects of diet on metabolic genes are often subtle but still physiologically relevant ${ }^{(50)}$, which also seemed to be the case in this study. Our data showed no temperature difference in retention of EPA or DHA, while others ${ }^{(51)}$ observed a non-significant tendency of increased $n-3$ retention at lower temperature $\left(2 v .8^{\circ} \mathrm{C}\right)$ in salmon parr. However, only retention of total $n-3$ FA was calculated in that study and the experiment was conducted in the freshwater stage, making direct comparisons with our data difficult.

At the dietary levels where the EPA + DHA requirement for optimal growth was fulfilled ( $>2.7 \%$ of FA), retention of these two FA together are around $100 \%$. Hence, salmon aquaculture would not need to diminish the world supply of these FA. However, using salmon for 'production' of long-chain $n-3$ FA does not seem like a realistic scenario. Furthermore, factors such as lower growth or increased economic FCR due to increased feed waste or mortalities in commercial 
farming compared with our experimental conditions will probably reduce the retention efficiency to less than $100 \%$.

Our results show that salmon will remain a good source of EPA and DHA for human nutrition also in the future. A 200 $\mathrm{g}$ portion of fillet of salmon fed diet 1:3.4 (fulfilling the requirements for optimal growth of the fish) in this study would provide about $1.25 \mathrm{~g} \mathrm{EPA}+\mathrm{DHA}$ (assuming an average fat content of $16 \%$ in the commercial product), which is five times the daily dose of $250 \mathrm{mg}$ to prevent the development of CVD in healthy adults recommended by the European Food Safety Authority ${ }^{(52)}$, while other recommendations are higher reviewed by $\mathrm{VKM}^{(53)}$.

\section{Conclusions}

Atlantic salmon have a specific requirement for EPA + DHA for optimal growth in the sea and the required level is $>2.7 \%$ of FA $(10 \mathrm{~g} / \mathrm{kg}$ feed DM in a typical salmon grower diet) equally at 6 and $12^{\circ} \mathrm{C}$. Our studies demonstrate that long-term trials are needed when $\mathrm{FA}$ requirement studies are carried out in post smolt salmon. Furthermore, salmon can be a net producer of DHA dependent on dietary supply, but retention increases significantly only when dietary levels drop below those required for optimal growth. Temperature $\left(6\right.$ or $\left.12^{\circ} \mathrm{C}\right)$ did not seem to have a major impact on the results obtained in the present study.

\section{Supplementary material}

The supplementary material for this article can be found at http://dx.doi.org/10.1017/jns.2016.10

\section{Acknowledgements}

Technical staff at the National Institute of Nutrition and Seafood Research (NIFES) and Skretting ARC Laboratory are thanked for excellent assistance with the chemical analyses. We would also like to thank the staff at the Skretting ARC Fish Trial station for excellent fish husbandry and particularly Tårn Helgøy Thomsen for taking care of all practical aspects related to the fish trials.

This work was supported by the Norwegian Regional Research Fund (grant number 217478) and the Norwegian Research Council (grant number 225086/E40) as well as Skretting ARC.

There were no conflicts of interest.

G. R. designed and planned the trials and had overall responsibility, B. E. T. designed the trials, I. S. formulated diets, participated in samplings and in writing of the manuscript, N. U. performed parts of the data analyses and N. H. S. participated in samplings, data analyses and writing of the manuscript.

All authors commented on the manuscript and approved the final version.

\section{References}

1. Tocher DR (2015) Omega-3 long-chain polyunsaturated fatty acids and aquaculture in perspective. Aquaculture 449, 94-907.
2. Sargent JR, Tocher DR \& Bell JG (2002) The lipids. Fish Nutr 3, 181-257.

3. National Research Council (2011) Nutrient Requirements of Fish and Shrimp. Washington, DC, USA: National Academies Press.

4. Lee D, Roehm J, Yu T, et al. (1967) Effect of $\omega 3$ fatty acids on the growth rate of rainbow trout, Salmo gairdnerii. J Nutr 92, 93-98.

5. Castell J, Sinnhuber R, Wales J, et al. (1972) Essential fatty acids in the diet of rainbow trout (Salmo gairdner): growth, feed conversion and some gross deficiency symptoms. J Nutr 102, 77-85.

6. Ruyter B, Røsjø C, Einen O, et al. (2000) Essential fatty acids in Atlantic salmon: effects of increasing dietary doses of $n-6$ and $n-3$ fatty acids on growth, survival and fatty acid composition of liver, blood and carcass. Aquacult Nutr 6, 119-127.

7. Glencross BD (2009) Exploring the nutritional demand for essential fatty acids by aquaculture species. Rev Aquacult 1, 71-124.

8. Waagbø R, Sandnes K, Sandvin A, et al. (1991) Feeding three levels of $n-3$ polyunsaturated fatty acids at two levels of vitamin $\mathrm{E}$ to Atlantic salmon (Salmo salar). Growth and chemical composition. Skr Ser Ernaering 4, 51-63.

9. Waagbø R, Sandnes K, Torrissen OJ, et al. (1993) Chemical and sensory evaluation of fillets from Atlantic salmon (Salmo salar) fed three levels of $n-3$ polyunsaturated fatty acids at two levels of vitamin E. Food Chem 46, 361-366.

10. Torstensen BE (2000) Transport and metabolism of lipids in Atlantic salmon (Salmo salar L.). PhD Thesis, University of Bergen.

11. Bell JG, McEvoy J, Tocher DR, et al. (2001) Replacement of fish oil with rapeseed oil in diets of Atlantic salmon (Salmo salar) affects tissue lipid compositions and hepatocyte fatty acid metabolism. J Nutr 131, 1535-1543.

12. Rosenlund G, Obach A, Sandberg M, et al. (2001) Effect of alternative lipid sources on long-term growth performance and quality of Atlantic salmon (Salmo salar L.). Aquacult Res 32, 323-328.

13. Bell JG, Henderson RJ, Tocher DR, et al. (2002) Substituting fish oil with crude palm oil in the diet of Atlantic salmon (Salmo salar) affects muscle fatty acid composition and hepatic fatty acid metabolism. J Nutr 132, 222-230.

14. Bell JG, McGhee F, Campbell PJ, et al. (2003) Rapeseed oil as an alternative to marine fish oil in diets of post-smolt Atlantic salmon (Salmo salar): changes in flesh fatty acid composition and effectiveness of subsequent fish oil "wash out". Aquaculture 218, 515-528.

15. Bell JG, Tocher DR, Henderson RJ, et al. (2003) Altered fatty acid compositions in Atlantic salmon (Salmo salar) fed diets containing linseed and rapeseed oils can be partially restored by a subsequent fish oil finishing diet. J Nutr 133, 2793-2801.

16. Regost C, Jakobsen JV \& Rørå AMB (2004) Flesh quality of raw and smoked fillets of Atlantic salmon as influenced by dietary oil sources and frozen storage. Food Res Int 37, 259-271.

17. Torstensen BE, Frøyland L, Ørnsrud R, et al. (2004) Tailoring of a cardioprotective muscle fatty acid composition of Atlantic salmon (Salmo salar) fed vegetable oils. Food Chem 87, 567-580.

18. Torstensen BE, Bell JG, Rosenlund G, et al. (2005) Tailoring of Atlantic salmon (Salmo salar L.) flesh lipid composition and sensory quality by replacing fish oil with a vegetable oil blend. J Agric Food Chem. 53, 166-178.

19. Stubhaug I, Lie $\varnothing$ \& Torstensen BE (2007) Fatty acid productive value and $\beta$-oxidation capacity in Atlantic salmon (Salmo salar L.) fed on different lipid sources along the whole growth period. Aquacult Nutr 13, 145-155.

20. Sanden M, Stubhaug I, Berntssen MH, et al. (2011) Atlantic salmon (Salmo salar L.) as a net producer of long-chain omega-3 fatty acids. J Agric Food Chem 59, 12697-12706.

21. Cossins AR \& Macdonald AG (1989) The adaptation of biological membranes to temperature and pressure: fish from the deep and cold. J Bioenerg Biomembr 21, 115-135.

22. Hazel JR \& Williams E (1990) The role of alterations in membrane lipid composition in enabling physiological adaptation of organisms to their physical environment. Prog Lipid Res 29, 167-227.

23. Kraffe E, Marty Y \& Guderley H (2007) Changes in mitochondrial oxidative capacities during thermal acclimation of rainbow trout 
Oncorbynchus mykiss: roles of membrane proteins, phospholipids and their fatty acid compositions. J Exp Biol 210, 149-165.

24. Turchini GM, Francis DS, Keast RS, et al. (2011) Transforming salmonid aquaculture from a consumer to a producer of long chain omega-3 fatty acids. Food Chem 124, 609-614.

25. Tocher DR, Fonseca-Madrigal J, Bell JG, et al. (2002) Effects of diets containing linseed oil on fatty acid desaturation and oxidation in hepatocytes and intestinal enterocytes in Atlantic salmon (Salmo salar). Fish Physiol Biochem 26, 157-170.

26. Buzzi M, Henderson R \& Sargent J (1996) The desaturation and elongation of linolenic acid and eicosapentaenoic acid by hepatocytes and liver microsomes from rainbow trout (Oncorbynchus mykiss) fed diets containing fish oil or olive oil. Biocbim Biophys Acta 1299, 235-244.

27. Ruyter B \& Thomassen M (1999) Metabolism of $n-3$ and $n-6$ fatty acids in Atlantic salmon liver: stimulation by essential fatty acid deficiency. Lipids 34, 1167-1176.

28. NMKL (1991) Moisture and ash. Gravimetric determination in meat and meat products. In NMKL no. 23, 3rd ed. Oslo, Norway: NMKL.

29. NMKL (2003) Nitrogen. Determination in foods and feds according to Kjeldahl. In NMKL no. 6, 4th ed. Oslo, Norway: NMKL.

30. NMKL (1998) Fat. Determination in foods. In NMKL no. 160. Oslo, Norway: NMKL.

31. Cunniffe P \& AOAC (1997) Oil, AOAC official method Ba 3-38. In Official Methods of Analysis of AOAC International. Gaithersburg, MD: AOAC.

32. Grahl-Nielsen O \& Barnung T (1985) Variations in the fatty acid profile of marine animals caused by environmental and developmental changes. Mar Environ Res 17, 218-221.

33. Sissener NH, Hemre G-I, Lall SP, et al. (2011) Are apparent negative effects of feeding GM MON810 maize to Atlantic salmon, Salmo salar, caused by confounding factors? Br J Nutr 106, 42-56.

34. Olsvik PA, Lie KK, Jordal A-EO, et al. (2005) Evaluation of potential reference genes in real-time RT-PCR studies of Atlantic salmon. BMC Molec Biol 6, 21.

35. Zheng X, Torstensen BE, Tocher DR, et al. (2005) Environmental and dietary influences on highly unsaturated fatty acid biosynthesis and expression of fatty acyl desaturase and elongase genes in liver of Atlantic salmon (Salmo salar). Biochim Biophys Acta 1734, 13-24.

36. Higuchi R, Fockler C, Dollinger G, et al. (1993) Kinetic PCR analysis: real-time monitoring of DNA amplification reactions. Biotechnology (N Y) 11, 1026-1030.

37. Torstensen B, Espe M, Sanden M, et al. (2008) Novel production of Atlantic salmon (Salmo salar) protein based on combined replacement of fish meal and fish oil with plant meal and vegetable oil blends. Aquaculture 285, 193-200.

38. Watanabe T (1982) Lipid nutrition in fish. Comp Biochem Physiol 73B, 3-15.

39. Glencross B, Smith D, Thomas M, et al. (2002) The effect of dietary $n-3$ and $n-6$ fatty acid balance on the growth of the prawn Penaeus monodon. Aquacult Nutr 8, 43-51.
40. Bell JG, Pratoomyot J, Strachan F, et al. (2010) Growth, flesh adiposity and fatty acid composition of Atlantic salmon (Salmo salar) families with contrasting flesh adiposity: effects of replacement of dietary fish oil with vegetable oils. Aquaculture 306, 225-232.

41. Morais S, Silva T, Cordeiro O, et al. (2012) Effects of genotype and dietary fish oil replacement with vegetable oil on the intestinal transcriptome and proteome of Atlantic salmon (Salmo salar). BMC Genomics 13, 448.

42. Glencross BD, Tocher DR, Matthew C, et al. (2014) Interactions between dietary docosahexaenoic acid and other long-chain polyunsaturated fatty acids on performance and fatty acid retention in post-smolt Atlantic salmon (Salmo salar). Fish Physiol Biochem 40, 1213-1227.

43. Robin J, Regost C, Arzel J, et al. (2003) Fatty acid profile of fish following a change in dietary fatty acid source: model of fatty acid composition with a dilution hypothesis. Aquaculture 225, 283-293.

44. Ruyter B, Røsjø C, Einen O, et al. (2000) Essential fatty acids in Atlantic salmon: time course of changes in fatty acid composition of liver, blood and carcass induced by a diet deficient in $n-3$ and n-6 fatty acids. Aquacult Nutr 6, 109-118.

45. Tocher DR (2003) Metabolism and functions of lipids and fatty acids in teleost fish. Rev Fisheries Sci 11, 107-184.

46. Sissener NH, Torstensen BE, Stubhaug I, et al. (2016) Long-term feeding of Atlantic salmon in seawater with low dietary long-chain $n-3$ fatty acids affects tissue status of brain, retina and erythrocytes. Br J Nutr (epublication ahead of print version 5 April 2016).

47. Olsen $Y$ \& Skjervold $H$ (1995) Variation in content of $\Omega 3$ fatty acids in farmed Atlantic salmon, with special emphasis on effects of non-dietary factors. Aquacult Int 3, 22-35.

48. Thomassen MS, Rein D, Berge GM, et al. (2012) High dietary EPA does not inhibit $\Delta 5$ and $\Delta 6$ desaturases in Atlantic salmon (Salmo salar L.) fed rapeseed oil diets. Aquaculture 360, 78-85.

49. Leaver MJ, Villeneuve LA, Obach A, et al. (2008) Functional genomics reveals increases in cholesterol biosynthetic genes and highly unsaturated fatty acid biosynthesis after dietary substitution of fish oil with vegetable oils in Atlantic salmon (Salmo salar). BMC Genomics 9, 299

50. Leaver MJ, Bautista JM, Björnsson BT, et al. (2008) Towards fish lipid nutrigenomics: current state and prospects for fin-fish aquaculture. Rev Fisheries Sci 16, 73-94.

51. Bendiksen E \& Jobling M (2003) Effects of temperature and feed composition on essential fatty acid $(n-3$ and $n-6)$ retention in Atlantic salmon (Salmo salar L.) parr. Fish Physiol Biochem 29, 133-140.

52. EFSA (2010) Opinion on dietary reference values for fats, including saturated fatty acids, polyunsaturated fatty acids, monounsaturated fatty acids, trans fatty acids and cholesterol. EFS A J 8, 1461

53. VKM (2014) Benefit-Risk Assessment of Fish and Fish Products in the Norwegian Diet - An Update. Oslo: Norwegian Scientific Committee for Food Safety. 